\title{
Modeling organic carbon dynamics under no-tillage and plowed systems in tropical soils of Brazil using CQESTR
}

\author{
L.F.C. Leite $^{\mathrm{a}, *}$, P.C. Doraiswamy ${ }^{\mathrm{b}}$, H.J. Causarano ${ }^{\text {b,c }}$, H.T. Gollany ${ }^{\mathrm{d}}$, S. Milak ${ }^{\mathrm{b}}$, E.S. Mendonca ${ }^{\mathrm{e}}$ \\ ${ }^{a}$ EMBRAPA Meio-Norte, Caixa Postal 01, Teresina, PI 64006-220, Brazil \\ ${ }^{\mathrm{b}}$ USDA-ARS, Hydrology and Remote Sensing Laboratory, Beltsville, MD 20705, USA \\ ${ }^{\mathrm{C}}$ Facultad de Ciencias Agrarias, San Lorenzo, Paraguay \\ dUSDA-ARS-PWA, Pendleton, OR 97801, USA \\ ${ }^{\mathrm{e}}$ Departamento de Solos, Universidade Federal de Viçosa, Viçosa, MG 36571-000, Brazil
}

\section{A R T I C L E IN F O}

\section{Article history:}

Received 7 February 2007

Received in revised form 30 April 2008

Accepted 10 August 2008

\section{Keywords:}

Soil organic matter

Carbon sequestration

Tillage systems

Simulation models

\begin{abstract}
A B S T R A C T
CQESTR simulates the effect of management practices on soil organic carbon (SOC) stocks. The beta version of the model had been calibrated and validated for temperate regions. Our objective was to evaluate the CQESTR model performance for simulating carbon dynamics as affected by tillage practices in two tropical soils (Ultisol and Oxisol) in southeastern and northeastern Brazil. In the southeast (20.75 S $42.81 \mathrm{~W}$ ), tillage systems consisted of no tillage (NT); reduced tillage (RT) (one disc plow and one harrow leveling [RT1] or one heavy disc harrow and one harrow leveling [RT2]); and conventional tillage (CT) (two heavy disc harrows followed by one disc plow and two harrow levelings). In the northeast (7.55 S $45.23 \mathrm{~W}$ ), tillage systems consisted of NT, RT (one chisel plow and one harrow leveling), and CT (one disk plow, two heavy disk harrowings, and two harrow levelings). CQESTR underestimated SOC at both sites, especially under NT systems, indicating that adjustments (e.g., the inclusion of clay mineralogy factor) are necessary for more accurate simulation of SOC in the tropics. In spite of this, measured and simulated values of SOC in the $0-20 \mathrm{~cm}$ depth were well correlated (southeast, $R^{2}=0.94, p<0.01$; northeast, $R^{2}=0.88, p<0.05$ ). With respect to initial conditions (native forest), CQESTR estimated a decrease in SOC stocks in plowed and no-tillage systems. In 2006, in the southeast, SOC stocks were 28.8, 23.7, 23.2, and $22.0 \mathrm{Mg} \mathrm{ha}^{-1}$ under NT, RT2, RT1, and CT, respectively; in the northeast, stocks were 36.0, 33.8, and $32.5 \mathrm{Mg} \mathrm{ha}^{-1}$ under NT, RT, and CT, respectively. The model estimated carbon emissions varying from 0.36 (NT) to $1.05 \mathrm{Mg} \mathrm{ha}^{-1}$ year $^{-1}$ (CT) in the southeast and from 0.30 (NT) to 0.82 (CT) Mg ha ${ }^{-1}$ year $^{-1}$ in the northeast. CQESTR prediction of SOC dynamics illustrates acceptable performance for the two tropical soils of Brazil.
\end{abstract}

(c) 2008 Elsevier B.V. All rights reserved.

\section{Introduction}

Restoring soil organic matter (SOM) levels in tropical soils is critical for sustainable crop production. In extensive croplands of Brazil, common management practices that remove straw at harvest and intensive cultivation have resulted in significant losses of SOM and nutrients for plant growth. In this respect, the adoption of no-tillage system is a viable mechanism to increase SOM and, therefore, soil organic carbon storage (Leite et al., 2004; Oliveira et al., 2004). Besides improving soil quality, an increase in SOM is viewed as a sink for atmospheric $\mathrm{CO}_{2}$ and, as a result, mitigates detrimental effects of global warming (Lal, 2004).

\footnotetext{
* Corresponding author. Tel.: +55 8630899185

E-mail address: luizf@cpamn.embrapa.br (L.F.C. Leite).
}

Soil organic matter simulation models are important tools for evaluating long-term effects of management systems on soil $\mathrm{C}$ and $\mathrm{N}$ dynamics. In such models, the relationships among several components are described explicitly, as is the influence of environmental conditions. Following appropriate calibration and validation, models can be used to study SOM dynamics and to explore the possibilities for modification of SOM content and/or composition through various intervention measures in the system (Shibu et al., 2006). Several SOM simulation models have been developed and evaluated during the past 30 years, for example, Century (Parton et al., 1987), RothC (Colleman and Jenkinson, 1996), DAISY (Hansen et al., 1990), and EPIC (William and Renard, 1985; Izaurralde et al., 2006). However, mechanistic models are often too complex and show multicompartmental structure based on qualitative concepts rather than measurable entities, and the required parameters or input variables are generally difficult to 
obtain. Thus, it is important that simpler but mechanistic SOM models be developed and validated under field conditions (Bruun et al., 2003; Hong-Jun et al., 2006).

CQESTR is a process-based model that simulates the effect of management practices on soil organic carbon stocks. It requires few input variables and these variables are readily available. Most of the required input data, including climate, is automatically extracted from existing crop management files associated with the c-factor files in the Revised Universal Soil Loss Equation (RUSLE, Renard et al., 1996). Monthly mean air temperature and precipitation can be automatically extracted from the city database files used by RUSLE files when local climatic data is not available. Daily average air temperature is estimated by fitting the annual temperature trend provided by the average monthly temperatures. Soil organic matter change is computed by maintaining a soil carbon budget, i.e., additions of biomass such as crop residue or amendments, and losses of organic carbon through microbial decomposition (Rickman et al., 2001). Main input variables include the number and thickness of soil layers, organic matter content and bulk density of each layer, aboveground and below-ground crop biomass, tillage operations, monthly average air temperature, monthly precipitation, and nitrogen content of residues at the beginning of decomposition.

In spite of CQESTR's simplicity, few studies have used it in temperate regions (Rickman et al., 2002; Hong-Jun et al., 2006) and none in tropical regions. Our objective was to evaluate CQESTR for simulating organic carbon dynamics in tropical soils of Brazil under no-tillage and plowed systems.

\section{Materials and methods}

\subsection{Study sites}

The model was evaluated with data from two experiments in Brazil. One experiment was established in 1985 at the Federal University of Vicosa Experimental Station, in Coimbra, Minas Gerais State (20.75 S $42.81 \mathrm{~W})$. The other experiment was established in 1994 at Boa Esperanca Farm, in Baixa Grande do Ribeiro (BGR), Piauí State (7.55 S $45.23 \mathrm{~W}$ ). The mean annual air temperature and average rainfall are $19{ }^{\circ} \mathrm{C}$ and $1350 \mathrm{~mm}$ at Coimbra and $25^{\circ} \mathrm{C}$ and $1200 \mathrm{~mm}$ at BGR. Two-thirds of this rain falls during the warmest season of the year, from October to April. Soils at the Coimbra field are Typic Hapludults and classified as "Argissolo VermelhoAmarelo" in the Brazilian classification scheme. The surface horizon (Ap) has a clay texture ( 460 g clay $\mathrm{kg}^{-1}$ ), low $\mathrm{pH}$ (5.1), and $1.73 \% \mathrm{C}$. Soils at the BGR field are Typic Hapludox, which is referred to as "Latossolo Vermelho-Amarelo" in the Brazilian classification scheme, with a clay texture (560 g clay $\mathrm{kg}^{-1}$ ), low $\mathrm{pH}(5.0)$, and $1.52 \% \mathrm{C}$ in the surface horizon.

In Coimbra, the area was covered by Atlantic Forest (AF) until 1930. After that, the land was cultivated for 54 years with major crops, such as maize (Zea mays L.) and common bean (Phaseolus vulgaris L.). An experiment was begun in 1985 that consisted of four tillage systems, arranged in a complete randomized block design, with four replications. Plots were $4 \mathrm{~m} \times 11 \mathrm{~m}$ under a maize-fallow-soybean (Glycine $\max$ L.) rotation. Tillage treatments were (1) no tillage (NT), minimal soil disturbance with crops being directly sown in summer on the residues of the weeds that grew up during the fallow; (2) reduced tillage-disk plow (RT1), plowing at $20-25 \mathrm{~cm}$ depth with a three-fixed-disk plow, in a single pass; (3) reduced Tillage-heavy disk harrow (RT2), one harrowing at $10-15 \mathrm{~cm}$ depth with a heavy disk harrower of 20 disks weighing approximately $2 \mathrm{t}$; and (4) conventional tillage (CT), heavy disk harrow plus disk plowing, one single pass at $0-$ $15 \mathrm{~cm}$ using a heavy disk harrow with 20 disks, followed by disk plowing at $20-25 \mathrm{~cm}$ depth with a three-fixed-disk plow.
In BGR, the area was originally covered by Cerrado (CER) vegetation (Savannah Forest) until 1990 and then was cultivated for 4 years with soybean under conventional tillage. An experiment was started at the end of 1994 consisting of three tillage systems arranged in a complete randomized block design with four replications; plots were $7.20 \mathrm{~m} \times 20 \mathrm{~m}$. The soil was cultivated with soybean, maize, or rice (Oryza sativa L.) during the wet season and with millet (Pennisetum glaucum L.) as a cover crop during the dry season. Tillage systems were (1) NT, minimal soil disturbance, with crops being directly sown in wet season on the residues of the weeds that grew up during the fallow; (2) RT, chisel plow and one harrow levelling; (3) CT, one disk plow, two heavy disk harrowings and two harrow levelings. Adjacent areas (100 m distance) with the same soil type and native vegetation were selected as reference plots at both locations. These plots were under secondary AF and native CER at Coimbra and BGR, respectively.

\subsection{Model description}

CQESTR simulates the effects of climate, crop rotation, and tillage management practices on soil organic C (Rickman et al., 2001). It works on a daily time-step and can perform long-term simulations (100 years). The model balances the effect of crop residue or soil amendment additions and losses by microbial oxidation of native SOM. In nature each organic addition to soil decomposes and is slowly incorporated into SOM. Crop residue and organic amendments are categorized by their placement in a soil layer. CQESTR can track up to five soil layers (horizons) of any depth. Each residue addition is tracked separately until it decomposes completely. As organic residues (shoot, root, or amendments) decompose their identities are maintained throughout the decomposition phases in each soil layer. Existing SOM is also tracked as a separate pool for each soil layer under consideration.

In CQESTR, it takes approximately 3.5-4 years, depending on cumulative degree days (CDD) or thermal time, before the remnants of a residue are considered sufficiently composted to be added to the stable SOM pool (Rickman et al., 2001). This thermal time value was determined by best-fit calibration of the model with long-term soil carbon observations. In the model, this transfer occurs as an abrupt step function on the date that composting is completed which is determined by CDD (Rickman et al., 2002).

Residue decomposition is simulated by an exponential function driven by cumulative heat units, with appropriate empirical coefficients for the type of residue, nitrogen content, and incorporation into the soil by tillage

$\mathrm{Rr}=\mathrm{IR} \times \exp (k \times \mathrm{fN} \times \mathrm{fW} \times \mathrm{fB} \times \mathrm{CDD})$

where $\mathrm{Rr}$ is the remaining residue in units of weight of residue per unit area; IR is the initial residue amount; $k$ is a universal decomposition rate constant, independent of residue type or location; $\mathrm{fN}$ is the nitrogen content factor and provides decomposition rates for nitrogen-rich (i.e. legume) or nitrogen-poor residues (i.e. cereal); $\mathrm{fW}$ is a water availability factor that depends on residue location (either buried or lying on the soil surface) as controlled by the timing and type of tillage and the presence or absence of sufficient water $(\sim 2.5 \mathrm{~cm})$ for maximum decomposition; $\mathrm{fB}$ is a biomass type factor; and CDD is the amount of heat accumulated in units of ${ }^{\circ} \mathrm{C}$ with a base temperature of $0{ }^{\circ} \mathrm{C}$. In this study the values of parameters in the decomposition equation were the same as suggested by Rickman et al. (2002). The values assigned to these parameters were as follow: fN was 0.8354 , $1.2635,1.9770$ or 3.4040 for $\mathrm{N}$ content of $<0.55 \%, 0.55 \% \leq$ to $<1 \%$, 
$1 \% \leq$ to $<1.5 \%$ and $\geq 1.5 \%$, respectively. Water availability factors (fW) values were $0.21,0.32,0.80$, and 1.0 for residue on the soil surface under dry condition, residue on the soil surface under wet condition, buried organic matter under dry condition, and buried organic matter under wet condition, respectively. Biomass type factor $(\mathrm{fB})$ values were $1.0,0.35,0.60$, and 0.0019 for crop residue, root biomass, pre-digested organic matter, and soil organic matter, respectively (Rickman et al., 2002).

For each type of crop biomass or residue added to a soil, the fraction on the surface and the fraction buried are tracked separately. The decomposition of fresh residues refers to the computed change in residue mass predicted by CQESTR on a daily basis. For the first 1000 degree-days for each biomass (referred to as rapid-phase decomposition), the decomposition rate is computed using the initial nitrogen content for each biomass to determine a value for $\mathrm{fN}$; location of the biomass in the soil is specified to determine a value for $\mathrm{fW}$ and biomass type for a value for $\mathrm{fB}$. After the rapid-phase decomposition is completed (with the passage of 1000 degree-days), the nitrogen factor ( $\mathrm{fN}$ ) is reduced to its minimum value $(\mathrm{NO}=0.8354)$ for all future decomposition of that residue regardless of its initial $\mathrm{N}$ content. Tillage operations conducted between growing seasons bury additional amounts of residues or amendments. Buried and surface amounts of residues are decomposed using a rate appropriate for their location (Rickman et al., 2002).

The following information is required by CQESTR: Crop biomass (above ground and below ground), dates of all residues or amendment additions and tillage operation, fraction of pre-tillage residue weight remaining on the soil surface after each tillage, depth of tillage, nitrogen content of residue at decomposition initiation, average daily air temperature expected throughout the time of interest, an approximate date for the first significant rain after harvest, number and thickness of soil layers, organic matter content, and bulk density of each layer (Rickman et al., 2002).

\subsection{Parameterization}

CQESTR was originally developed and evaluated with data sets from three wheat-fallow rotations (with either fall burning of wheat residue, nitrogen fertilizer application or a manureamended wheat-fallow treatment) at the Pendleton Agricultural Research Center in Pendleton, Oregon. All parameters values determined from these previous studies were left unchanged. These parameters include SOM decomposition rate and empirical coefficients for fN, fW and fB.

Monthly minimum and maximum air temperature and precipitation were obtained from weather stations at the Vicosa Federal University (1967-2004) and at the Boa Esperanca Farm (1989-2004). Soil properties, such as SOM content, bulk density, soil texture class, and soil drainage class, were obtained from the field experiment at Coimbra and BGR. Crop yields, row spacing, plants population, root mass per acre (in the top 4 in.), and canopy cover were obtained from the field experiment and literature. Tillage, planting, fertilization, and harvesting operation dates were based on experimental records. Main input variables are shown in Table 1.

We made two changes to CQESTR's source code for improving accuracy for our study area. First, an option that allows two crops (or cover crop) per year was added. For cover crop, we simulated the addition of millet residues at a rate of $6 \mathrm{Mg} \mathrm{ha}^{-1}$ year $^{-1}$. Second, we added a decomposition factor to account for differences in SOM decomposition rate affected by types and number of tillage operation; this was necessary to represent more effectively the management practices that we evaluated. The values established were $1,1.08,1.13$, and 1.28 for no-tillage, reduced tillage with heavy harrow, reduced tillage with disk plow, and conventional tillage, respectively.

For the Coimbra experiment, we simulated SOM dynamics for 55 years (1930-1984), representing AF conversion into cropland and, later, for 56 years (1985-2040), representing different tillage systems. For the experiment at BGR, simulations were run initially for 5 years (1990-1994) to represent the Cerrado native vegetation conversion into cropland and for 46 years (1995-2040) to represent tillage systems adoption.

\subsection{Evaluation}

Soil organic carbon stocks measured for model validation were from samples collected in 1985, 1988, 1990, and 2000 at Coimbra, and in 2003, 2005, and 2006 at BGR. Soil samples were analyzed using a wet digestion procedure with potassium dichromate and sulfuric acid under heating (Yeomans and Bremner, 1988).

The agreement between simulated $(Y)$ and measured $(X)$ values after model calibration was assessed with (a) linear regression relating simulated to measured values with intercept not significantly different from zero and slope not significantly different from unity and (b) mean squared deviations (MSD) and its components.

Mean squared deviation was calculated as the sum of squared deviations between $X$ and $Y$, divided by the number of observations:

$\mathrm{MSD}=\frac{1}{n} \sum_{i=1}^{n}\left(Y_{i}-X_{i}\right)^{2}$

where $Y_{i}$ and $X_{i}$ are predicted and observed values, respectively. On perfect equality with $Y=X, M S D=0$. The MSD statistic was partitioned into three components (Kobayashi and Salam, 2000; Gauch et al., 2003): (a) inequality of means,

$\mathrm{IM}=(\bar{X}-\bar{Y})^{2}$

(b) nonunity mean square, defined as

$\mathrm{NU}=(1-b)^{2} \times\left(\frac{\sum x_{n}^{2}}{N}\right)$

where $b$ is the slope of the regression of $Y$ on $X$ and $x_{n}=X_{n}-\bar{X}$ measures the degree of rotation of the regression line, and (c) lack of correlation mean square,

$\mathrm{LC}=\left(1-r^{2}\right) \times\left(\frac{\sum y_{n}^{2}}{N}\right)$

where $r^{2}$ is the square of the correlation and $y_{n}=Y_{n}-\bar{Y}$.

Carbon sequestration potential estimated by $\operatorname{CQESTR}(0-20 \mathrm{~cm})$ was compared to measured values in 2000 (Coimbra) and 2006 (BGR). Mean Residence Time (MRT) was calculated as the inverse of

Table 1

Input variables for CQESTR simulation in two tropical soils $(0-20 \mathrm{~cm})$ under different tillage systems

\begin{tabular}{lll}
\hline & Ultisol (Coimbra) & Oxisol (BGR) \\
\hline Soil variables & & \\
Texture class & Sandy clay & Clay \\
Bulk density $\left(\mathrm{Mg} \mathrm{m}^{-3}\right)$ & 01.13 & 01.33 \\
Initial SOM $\left(\mathrm{g} \mathrm{kg}^{-1}\right)$ & 49.9 & 30.4 \\
Drainage class & Well drained & Well drained \\
Monthly weather variables & & \\
Mean total precipitation $(\mathrm{mm}$ month & -1 \\
Mean max. temperature $\left({ }^{\circ} \mathrm{C}\right)$ & 140 & 110 \\
Mean min. temperature $\left({ }^{\circ} \mathrm{C}\right)$ & 26.4 & 31.7 \\
\hline
\end{tabular}


decomposition constant (1/k) (Tiessen and Cuevas, 1994)

$C=C_{i} \mathrm{e}^{-k t}$

where $C_{i}$ is carbon content at the beginning of the experiment (Coimbra,1985; BGR, 1994) and $t$ is time in years.

\section{Results and discussion}

\subsection{Model evaluation}

CQESTR underestimated SOC stocks for both sites (Fig. 1). In spite of this, differences between simulated and measured values were small in the Ultisol, except in 1990. Perhaps this could be due to sampling technique-residue or particulate OM was not removed from the samples before SOM measurement, resulting in overestimation of actual decomposed SOM. Larger differences were found for no-tillage systems than for reduced and conventional systems, varying from 3.7 (1995) to 10\% (2000). For the RT1, CT, and RT2 systems, the differences were 2.4 (1985) to $8.9 \%$ (2000), 1.8 (1985) to $12.2 \%$ (1995), and 0.06 (1995) to 9.0\% (1988), respectively. In 2000, using the Century model for the same experiment, estimated differences between simulated and measured SOC stocks were $0.3,0.4$, and $4.0 \%$ for NT, CT, and RT1, respectively (Leite et al., 2004). These differences were lower than estimated SOC stocks by CQESTR, except that both Century and
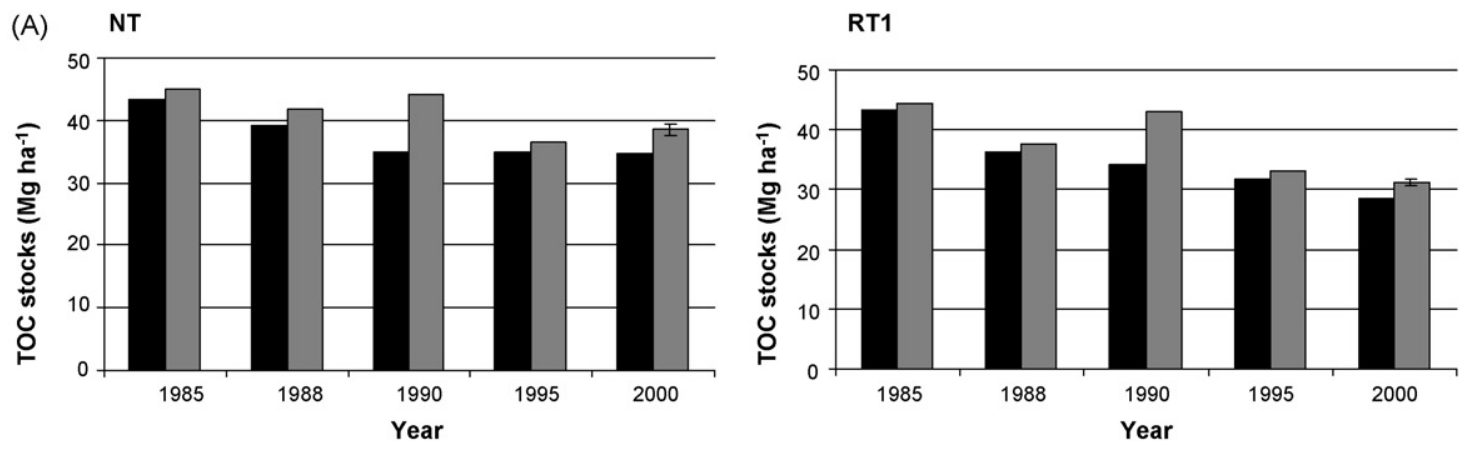

RT2
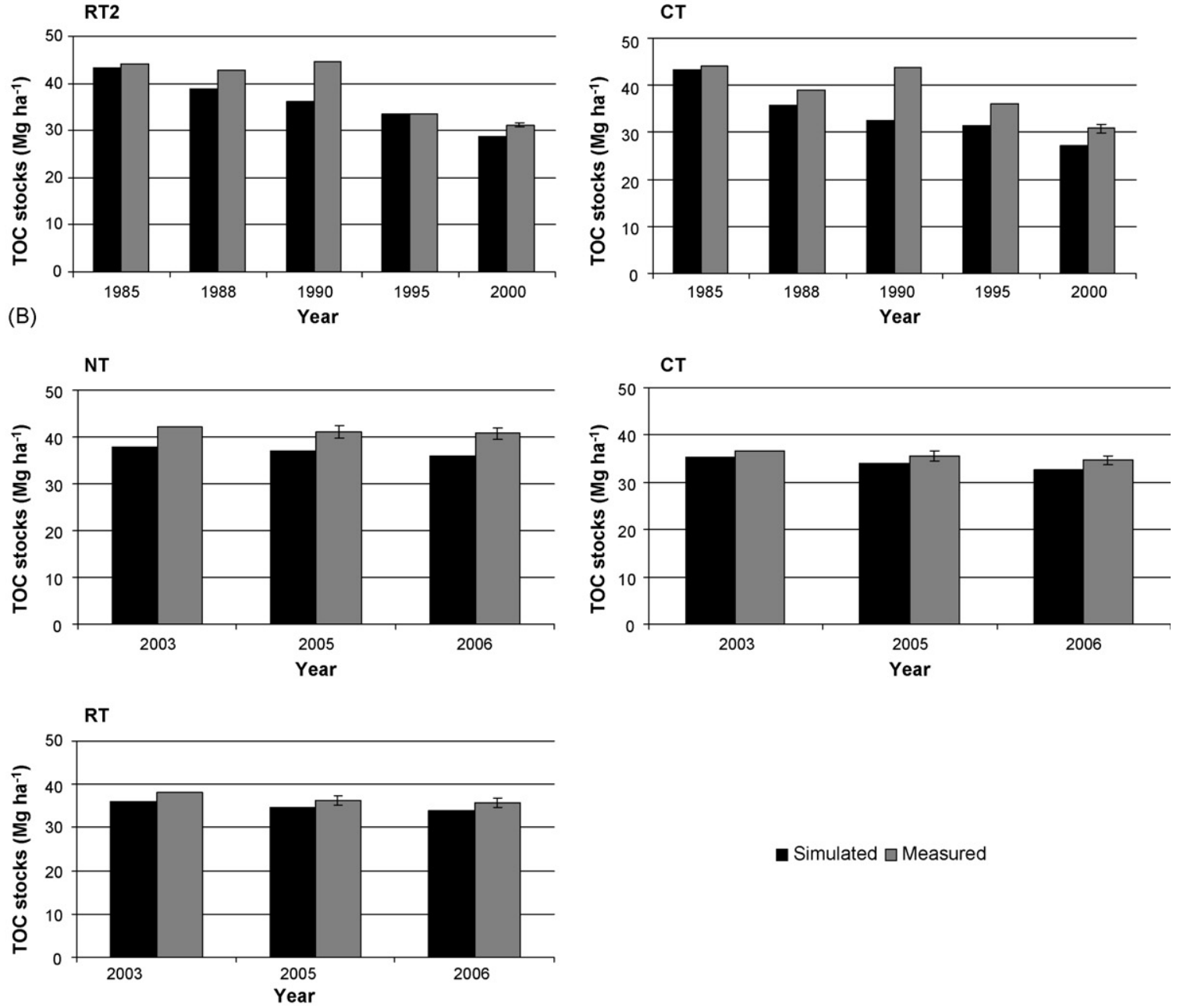

- Simulated $\square$ Measured

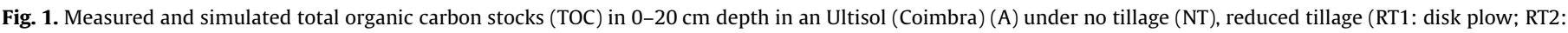
heavy disk harrow), and conventional tillage (CT) and in an Oxisol (BGR) (B) under NT, reduced tillage (RT), and CT. 
CQESTR predictions were similar for RT2 (7\%). However, since CQESTR is a simpler model with fewer input variables, these results can be considered acceptable.

In the Oxisol, CQESTR underestimation of SOC stocks was lower than those observed in the Ultisol. The differences between simulated and measured values were 4.0 (2005) to 4.6\% (2006) (NT), 1.25 (2003) to $2.19 \%$ (2006) (CT), and 1.61 (2005) to $2.23 \%$ (2003) (RT), showing that CQESTR more accurately simulated reduced and conventional tillages than the no-tillage system. This trend indicates that input residue to the soil, especially from cover crop, should be better represented by the model for tropical conditions.

Underestimation of SOC stocks has been observed in other models (e.g., Century) and is directly related to lack of important mechanisms of $C$ stabilization in tropical soils. As many tropical soils are dominated by variable-charge minerals with low cation exchange capacity (CEC), organic matter becomes very important for the nutrient status of the soils (Mendonça and Rowell, 1996). Since the climatic conditions of the Tropics promote fast soil organic matter decomposition, especially after forest clearing, tropical soils would be very poor in organic matter without this stabilization process. Three main mechanisms of $C$ stabilization have been proposed: (1) biochemical stabilization, due to the recalcitrance of compounds such as lignin and polyphenols, (2) physical protection within aggregate structure, and (3) stabilization by association with silt and clay particles (Six et al., 2002). Several studies have reported a relationship between clay content and preservation of organic C in tropical soils (Neufeldt et al., 2002; Roscoe and Buurman, 2003). CQESTR considers only texture effects. However, soils with the same textural class may show different clay content and different clay minerals, as result, will have different CECs, which, in turn, influence differently the $C$ stabilization. In our study, Ultisol and Oxisol have the same textural class but different clay content ( 46 and $56 \%$, respectively), which can improve $C$ stabilization with a consequent increase in SOC stocks in the Oxisol. In addition to the clay content, the model predictions may be improved by addition of clay type factor, which can modify $C$ turnover rates in these soils. In Brazil, the soils are dominated by variable-charge clay minerals such as kaolinite and, especially, Fe and Al oxides, which have a high flocculation capacity due to electrostatic interactions through their positive charges. Numerous authors have reported that the strong adsorption of SOM to active $\mathrm{Al}$ and Fe oxides is the cause for SOM stability in tropical soils; therefore, the interaction of organic compounds with clay in highly weathered oxidic soils can prevent SOM losses (Bronick and Lal, 2005; Bayer et al., 2006a). The lack of clay type effect in CQESTR and the magnitude of organic/inorganic complexation mainly in Oxisols, can explain partially the underestimation of simulated SOC stocks.

In spite of CQESTR's underestimation of SOC stocks, the correlation is good for Ultisol $\left(R^{2}=0.94 ; p<0.01\right)$ (Fig. 2). This conclusion is in agreement with that obtained by Hong-Jun et al. (2006). They evaluated CQESTR at seven sites in China and reported a good correlation $\left(R^{2}=0.94 ; p<0.05\right)$ between simulated and measured values. The highest contributing component of MSD was inequality of means for both sites ( 75 and 82\%) followed by the lack of correlation (Ultisol) and nonunity mean square (Oxisol) (Fig. 2). These results help explain CQESTR's performance. Measured and simulated values were highly correlated (low LC), but measured and simulated means were different (high IM), and slope was different from unity for Oxisol (high NU), indicating that the model is better able to simulate SOC dynamics under different management systems in some tropical soils than others.
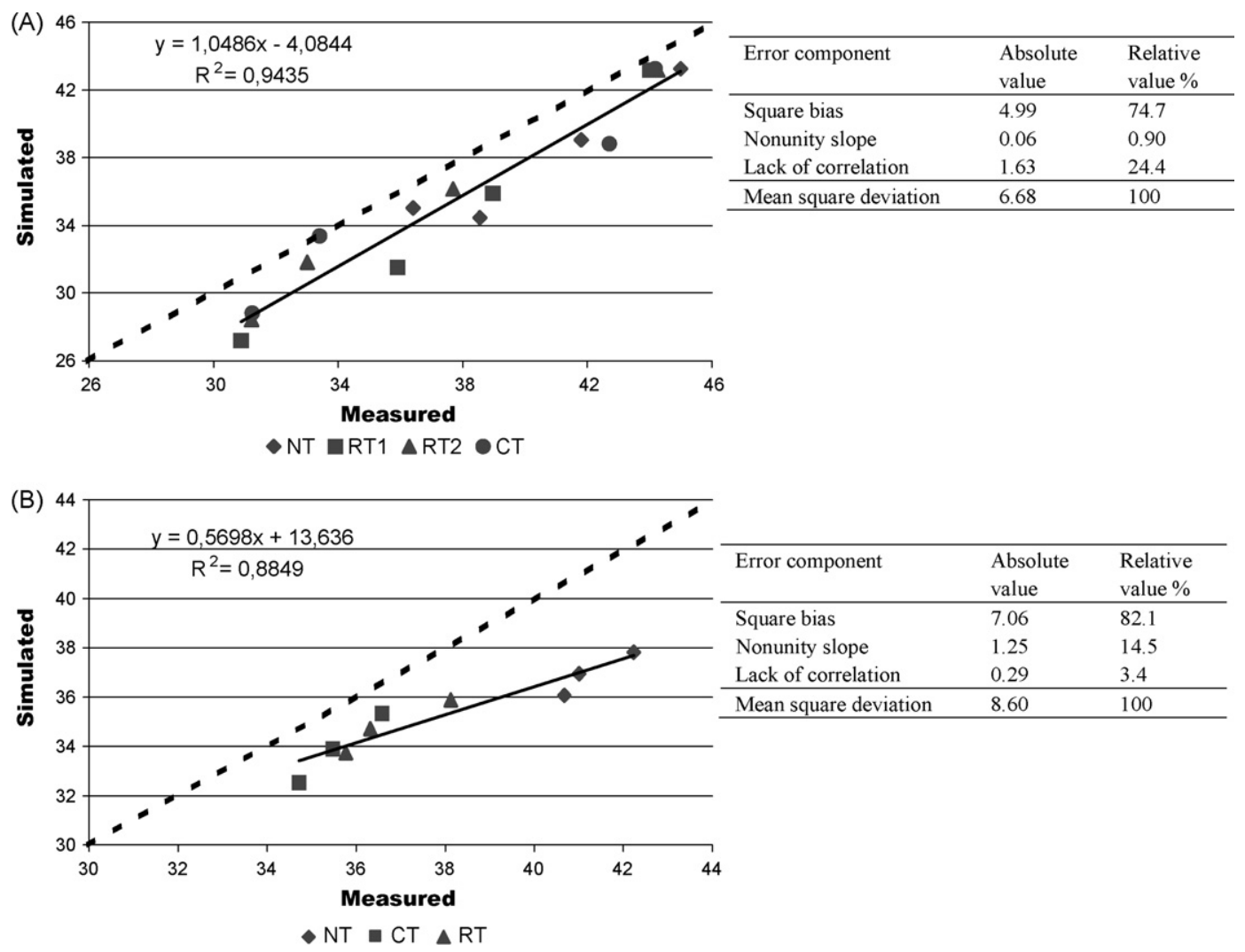

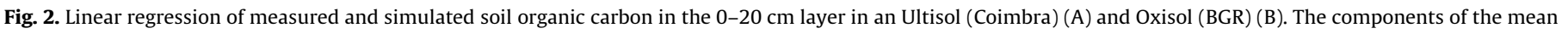
square deviation are included. 


\subsection{Trends in SOC stocks}

CQESTR estimated a decrease in SOC stocks after native forest was converted to cropland (Fig. 3). At Coimbra (Ultisol), SOC stock in 1985 (beginning of the experiment) was $34 \mathrm{Mg} \mathrm{ha}^{-1}$, which represents a $47 \%$ decrease with respect to SOC stocks under the Atlantic Forest. Reduction in SOC stocks after forest clearing is high in tropical soils due to high decomposition rates in response to warm temperature and high precipitation regimes, especially under intensive tillage, and may vary between 30 and 50\% (Shang and Tiessen, 1997; Machado and Silva, 2001). The reduction in SOC stocks estimated by CQESTR was greater than the 37\% decrease estimated by Century for the same experiment (Leite et al., 2004). However, if soil bulk density in 1985 is used for calculation of C stocks, the CQESTR estimate would be only 3\% greater than the Century estimate. As with many SOM simulation models, CQESTR does not consider tillage-induced changes in bulk density; consequently, SOC stocks can be underestimated since bulk density generally decreases with tillage operations (Lal et al., 1989). All tillage systems showed a decreasing trend in SOC stocks. In 2006, the values were $28.8,23.7,23.3$, and $22.0 \mathrm{Mg} \mathrm{ha}^{-1}$, for NT, RT2, RT1, and CT, respectively (Fig. 3), representing from 15 (NT) to $35 \%$ (CT) decreases with respect to SOC stocks at the beginning of the experiment. Two reasons for this reduction are (1) the long period under conventional tillage ( 55 years) before the experiment began and (2) that no cover crop was used in the NT system.

At BGR (Oxisol), CQESTR also estimated a decrease in SOC stocks after conversion from the Cerrado vegetation to cropland. The SOC stock measured under native forest was $48 \mathrm{Mg} \mathrm{ha}^{-1}$, while SOC stock was $42 \mathrm{Mg} \mathrm{ha}^{-1}$ at the beginning of the experiment, in 1994 (Fig. 3). A 10\% decrease in SOC stocks at BGR was lower than the $47 \%$ decrease at Coimbra. This is probably because BGR has been under conventional tillage for a shorter time (4 years) and also because of higher soil clay content at BGR, since the model uses a lower decomposition rate for heavier soil texture. Lower precipitation in this region could have affected microbial activity and, consequently, lowered degradation rates. Also, this is an Oxisol with high variable charge from iron and Al oxides that could have stabilized organic matter; consequently, it will have relatively higher SOC (Martin and Haider, 1986; Oades et al., 1989; Oades, 1995).

In the Cerrado region, the conventional system is considered to be one of the most degradative systems of land use, which often leads to a reduction of C stocks in soil (Bustamante et al., 2006). Soil degradation process affects soil quality and crop productivity, which reduces $C$ inputs to the soil. Silva et al. (1994) evaluated 220 Cerrado soils $(0-15 \mathrm{~cm},>30 \%$ clay) cultivated with soybean and verified losses of $41 \%$ in SOC after 5 years of cultivation. On the other hand, less intense changes have been observed, such as the results of our study and those reported by Roscoe and Buurman (2003). Roscoe and Buurman (2003) observed no changes in SOM stocks $(0-40 \mathrm{~cm})$ for a clayey Oxisol after 30 years of maize-bean cropping rotation. Low SOC losses can be attributed to the high stability of SOM in Cerrado soils caused by a bonding effect of Fe and $\mathrm{Al}$, as established by several authors (Zinn et al., 2005; Bayer et al., 2006a). Clay and organic matter interaction may increase organic-mineral bond formation that could protect organic matter from microbial decomposition due partly to adsorption on clay surface (Oades, 1988) and partly due to physical inaccessibility of organic matter within the soil micro-aggregates (Tisdall and Oades, 1982).

The decline in SOC stocks continued after tillage systems adoption. In 2006, SOC stocks estimated by the model were 36,34 , and $32 \mathrm{Mg} \mathrm{ha}^{-1}$ for NT, RT, and CT, respectively, which means a reduction of 16,20 , and $25 \%$ in SOC stocks since the beginning of
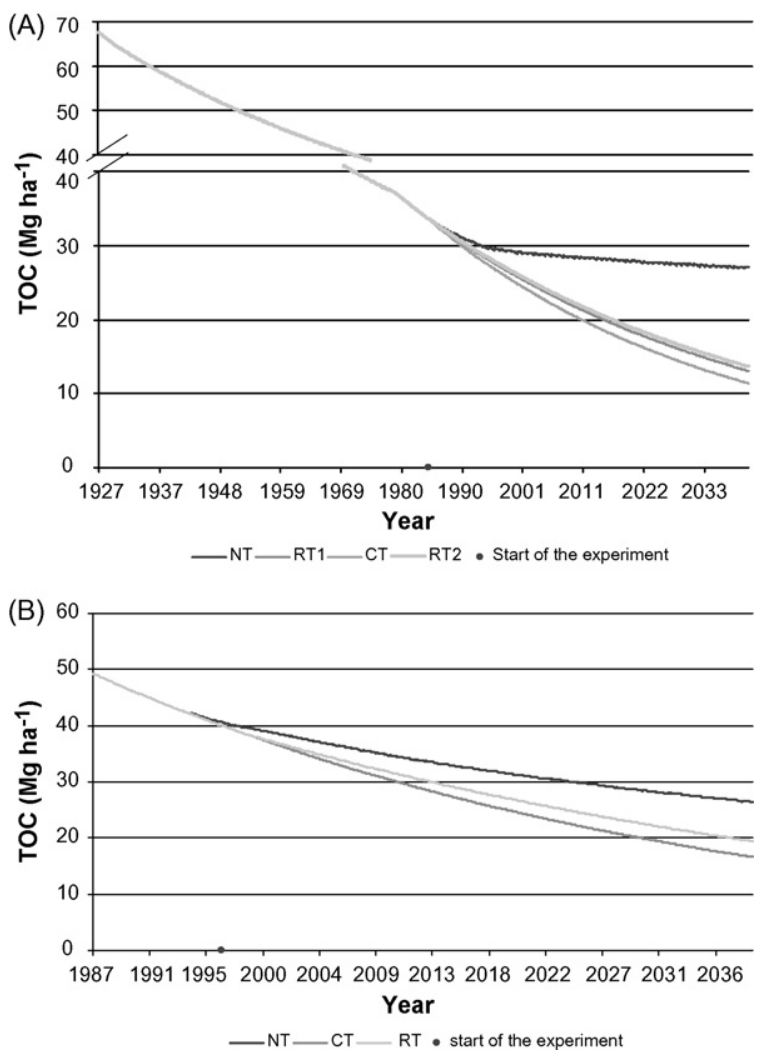

Fig. 3. Soil organic carbon dynamic $(0-20 \mathrm{~cm})$ simulated by CQESTR in an Ultisol (Coimbra) (A) under no tillage (NT), reduced tillage (RT1: disk plow; RT2: heavy disk harrow), and conventional tillage (CT) and in an Oxisol (BGR) (B) under NT, reduced tillage (RT), and CT.

the experiment. In this case, the model predicted that residue obtained from the cover crop $\left(6 \mathrm{Mg} \mathrm{ha}^{-1}\right)$ added was not enough to increase SOC stocks in this acidic tropical soil.

\subsection{Net changes in $\mathrm{SOC}$}

For the Ultisol, CQESTR estimated that tillage systems are emitting 0.36 and $1.05 \mathrm{MgCha}^{-1}$ year $^{-1}$ under NT and CT, respectively. Measured values also indicated that all tillage systems (including NT) emitted C; however, they were smaller in magnitude (Table 2). These estimates differ from others reported elsewhere showing carbon sequestration under no-tillage systems. We used $C$ stocks at the beginning of the experiment as a reference for calculations. On the other hand, if estimates for 2000 were based on C stocks for NT and CT, C sequestration on the order of 0.47 (simulated) and $0.48 \mathrm{Mg} \mathrm{ha}^{-1}$ year $^{-1}$ (measured) would be reported for the $20-\mathrm{cm}$ depth. When estimates are based on the difference between NT and CT, they agree well with published sequestration rates of $0.52 \mathrm{Mg} \mathrm{ha}^{-1}$ year $^{-1}$ for Ultisols in Brazil (Lovato et al., 2004).

In the Oxisol, $\mathrm{C}$ emissions were also observed, and varied from 0.30 (NT) to 0.82 (CT) when estimated by CQESTR, and from 0.14 (NT) to $0.84 \mathrm{Mg} \mathrm{ha}^{-1}$ year $^{-1}$ (CT) when calculated from measured values. Like the Ultisol, the highest difference between simulated and measured values was observed in the no-tillage system (53\%) compared with conventional (2\%) and reduced (4\%) tillage systems (Table 2). Considering SOC stocks in conventional tillage plots as the baseline, in 2006, NT estimated and measured annual C sequestration rates were 0.18 and $0.38 \mathrm{Mg} \mathrm{ha}^{-1}$ year $^{-1}$, respectively. Carbon sequestration rates in Brazilian Oxisols vary depending on clay content and number of years of the experiment. 
Table 2

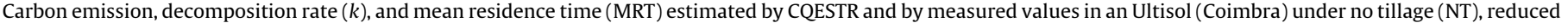
tillage (RT1: disk plow; RT2: heavy disk harrow), and conventional tillage (CT) and in an Oxisol (BGR) under NT, reduced tillage (RT), and CT at 0-20 cm depth

\begin{tabular}{|c|c|c|c|c|c|c|c|}
\hline \multirow[t]{2}{*}{ Tillage system } & \multicolumn{3}{|c|}{ SOC stock (Mg ha $\left.{ }^{-1}\right)$} & \multirow[t]{2}{*}{ Rate $\left(\mathrm{Mg} \mathrm{ha}^{-1}\right.$ year $\left.^{-1}\right)$} & \multirow[t]{2}{*}{ C Emission $\left(\mathrm{Mg} \mathrm{ha}^{-1}\right.$ year $\left.^{-1}\right)$} & \multirow[t]{2}{*}{$k$} & \multirow[t]{2}{*}{ MRT (year) } \\
\hline & Initial & Final & Variation, $\Delta$ & & & & \\
\hline \multicolumn{8}{|c|}{ Ultisol (Coimbra) } \\
\hline \multicolumn{8}{|c|}{ CQESTR } \\
\hline NT & 43.4 & 34.79 & -8.60 & -0.53 & -0.36 & 0.014 & 72 \\
\hline RT1 & 43.4 & 28.45 & -14.94 & -0.93 & -0.96 & 0.026 & 37 \\
\hline $\mathrm{CT}$ & 43.4 & 27.18 & -16.21 & -1.01 & -1.05 & 0.029 & 35 \\
\hline RT2 & 43.4 & 28.80 & -14.59 & -0.91 & -0.94 & 0.026 & 39 \\
\hline \multicolumn{8}{|l|}{ Measured } \\
\hline NT & 44.0 & 38.54 & -5.46 & -0.34 & -0.17 & 0.008 & 128 \\
\hline RT1 & 44.0 & 31.23 & -12.77 & -0.79 & -0.82 & 0.021 & 49 \\
\hline $\mathrm{CT}$ & 44.0 & 30.90 & -13.10 & -0.82 & -0.86 & 0.022 & 48 \\
\hline RT2 & 44.0 & 31.24 & -12.76 & -0.79 & -0.82 & 0.021 & 50 \\
\hline \multicolumn{8}{|l|}{ Oxisol (BGR) } \\
\hline \multicolumn{8}{|l|}{ CQESTR } \\
\hline NT & 42.7 & 36.07 & -6.63 & -0.51 & -0.30 & 0.013 & 77 \\
\hline $\mathrm{CT}$ & 42.7 & 32.53 & -10.17 & -0.78 & -0.82 & 0.021 & 48 \\
\hline RT & 42.7 & 33.75 & -8.95 & -0.69 & -0.72 & 0.018 & 55 \\
\hline \multicolumn{8}{|l|}{ Measured } \\
\hline NT & 45.1 & 40.68 & -4.42 & -0.34 & -0.14 & 0.009 & 126 \\
\hline $\mathrm{CT}$ & 45.1 & 34.72 & -10.38 & -0.80 & -0.84 & 0.022 & 49 \\
\hline RT & 45.1 & 35.76 & -9.34 & -0.72 & -0.75 & 0.019 & 56 \\
\hline
\end{tabular}

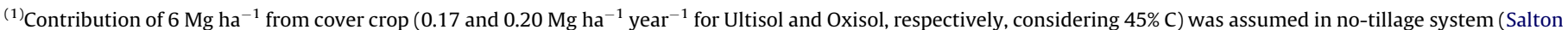

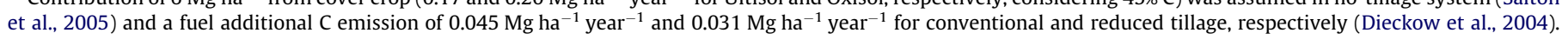

Freitas et al. (2000) estimated an annual $C$ sequestration rate of $0.25 \mathrm{Mg} \mathrm{ha}^{-1}$ year $^{-1}$ (50\% clay; 4 years) while Bayer et al. (2006b) calculated $0.30 \mathrm{Mg} \mathrm{ha}^{-1}$ year $^{-1}$ (35\% clay; 8 years), which is similar to $0.35 \mathrm{Mg} \mathrm{ha}^{-1}$ year $^{-1}$ ( $50 \%$ clay; 5 years) observed by Metay et al. (2006). In longer experiments, Corazza et al. (1999) and Oliveira et al. (2004) observed a C sequestration rate of 0.50 (40-50\% clay; 15 years) and $0.52 \mathrm{Mg} \mathrm{ha}^{-1}$ year $^{-1}$ (41\% clay; 20 years), respectively. Compared with these values, CQESTR underestimated $C$ sequestration rate for this Oxisol.

In the Ultisol, the decomposition rate $(k)$ varied from 0.014 (NT) to 0.029 year $^{-1}(\mathrm{CT})$ and from 0.008 (NT) to 0.022 year $^{-1}(\mathrm{CT})$, and in the Oxisol from 0.013 (NT) to 0.021 year $^{-1}$ (CT) and 0.009 (NT) to 0.022 year $^{-1}$ (CT) estimated by the model and by measured values, respectively (Table 2). CQESTR estimates for NT are very similar to those of Bayer (1996) that reported decomposition rates of 0.012 year $^{-1}$ for NT and 0.014 year $^{-1}$ for CT from a one compartment $\mathrm{C}$ model, in a 20-year-old experiment on a clayey

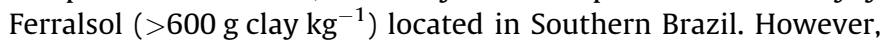
CQESTR overestimated decomposition rates for the CT system compared to Bayer (1996). On the other hand, decomposition rate values estimated by CQESTR were lower than values $(\mathrm{NT}=0.019$; $\mathrm{CT}=0.040$ ) reported by Bayer et al. (2006c) in the same climatic

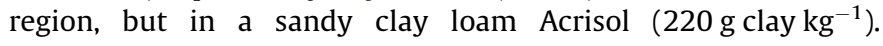
Decomposition rate values estimated by CQESTR were lower probably due to the high clay content observed in our study.

The reduced rate of decomposition under no-till was reflected in estimates of mean residence time (MRT) at both experiments. In the Ultisol, MRT was 72 and 128 years for NT versus 34 and 48 years for CT, and in the Oxisol MRT was 77 and 126 years for NT versus 48 and 49 years for CT, estimated by the model and calculated from measured values, respectively (Table 2 ). According to CQESTR estimates, the MRT was 2.0 times greater under NT than CT, which corresponds well with MRT of 1.5 observed for several temperate soils (Six et al., 2002). The fast turnover of soil aggregates in intensively tilled systems (compared with no-till) increases decomposition of SOM due to greater soil respiration and exposes relatively young and labile organic matter to decomposi- tion. This accelerated turnover also inhibits the formation and stabilization of more recalcitrant organic matter fractions within micro-aggregates that have a longer residence time in soil (Six et al., 1999; Paustian et al., 2000).

\section{Conclusion}

The CQESTR model simulations in general underestimated SOC stock at two study sites in Brazil. Underestimation was particularly pronounced under no-tillage system. The conversion from native forest to croplands greatly reduced the SOC stocks irrespective of the tillage practices. Crop residue was a major factor in maintaining or reducing the loss of SOC.

More studies are needed to evaluate the CQESTR model's performance for simulating SOC dynamics in tropical soils. Further adjustments, such as inclusion of clay mineralogy and organic matter interaction might be necessary to improve the model's estimates. Nevertheless, the model showed acceptable performance to predict SOC dynamic in two tropical soils of Brazil.

\section{Acknowledgments}

Funding for this research was primarily provided by the Global Climate Change Team, US Agency for International Development, Washington, DC. The authors would like to acknowledge the Agricultural Research Service of the U.S. Department of Agriculture for providing partial funding to support this project.

\section{References}

Bayer, C., 1996. Dinâmica da matéria orgânica do solo em sistemas de manejo de solos. PhD. Thesis. Universidade Federal do Rio Grande do Sul, Porto Alegre, Brasil.

Bayer, C., Martin-Neto, L., Mielniczuk, J., Dieckow, J., Amado, T.J.C., 2006a. C and N stocks and the role of molecular recalcitrance and organomineral interaction in stabilizing soil organic matter in a subtropical Acrisol managed under notillage. Geoderma 91, 217-226. 
Bayer, C., Martin-Neto, L., Mielniczuk, J., Pavinato, A., Dieckow, J., 2006b. Carbon sequestration in two Brazilian Cerrado soils under no-till. Soil Till. Res. 86, 237245.

Bayer, C., Lovato, T., Dieckow, J., Zanatta, J.A., Mielniczuk, J., 2006c. A method for estimating coefficients of soil organic matter dynamics based on long-term experiments. Soil Till. Res. 91, 217-226.

Bronick, C.J., Lal, R., 2005. Soil structure and management: a review. Geoderma 124 3-22.

Bruun, S., Christensen, B.T., Hansen, E.M., Magrid, J., Jensen, L.S., 2003. Calibration and validation of the soil organic matter dynamics of the Daisy model with data from the Askov long-term experiments. Soil Biol. Biochem. 35, 67-76.

Bustamante, M.C., Corbeels, M., Scopel, E., Roscoe, R., 2006. Soil carbon storage and sequestration potential in the Cerrado Region of Brazil. In: Lal, R., Cerri, C.C., Bernoux, M., Etchevers, J., Cerri, E. (Eds.), Carbon Sequestration in Soils of Latin America. The Haworth Press, Binghamton, USA, pp. 285-299.

Colleman, K., Jenkinson, D.S., 1996. RothC 26.3-a model for the turnover of carbon in soil. In: Polwson, T.S., Smith, P., Smith, J.U. (Eds.), Evaluation of Soil Organic Matter Models Using Existing Long Term Datasets. NATO ASI, Series I, vol. 38. Kluwer Academic Publishers, Dordrecht, Netherlands, pp. 237-246.

Corazza, E.J., Silva, J.E., Resck, D.V.S., Gomes, A.C., 1999. Comportamento de diferentes sistemas de manejo como fonte de depósito de carbono em relacão vegetacão de cerrado. Rev. Bras. Ci Solo 23, 425-432.

Dieckow, J., Bayer, C., Martin-Neto, L., Mielniczuk, J., 2004. Sistemas conservacionistas de preparo do solo e implicacõoes no ciclo do carbono. In: Embrapa Instrumentacão Agropecuária, Sao Carlos, Brazil, 17 pp.

Freitas, P.L., Blancaneaux, P., Gavinelli, E., Larre-Larrouy, M.C., Feller, C., 2000. Nível e natureza do estoque orgânico de latossolos sob diferentes sistemas de uso e manejo. Pesq. Agrop. Bras. 35, 157-170.

Gauch Jr., H.G., Hwang, J.T.G., Fick, G.W., 2003. Model evaluation by comparison of model-based predictions and measured values. Agron. J. 92, 1442-1446.

Hansen, S., Jensen, H.E., Nielsen, N.E., Svendsen, H., 1990. DAISY: Soil Plant Atmosphere System Model. NPO Report N. A 10. The National Agency for Environmental Protection, Copenhagen, 272 pp.

Hong-Jun, L., Bao-Guo, L., You-Lu, B., Yuan-Fang, H., Yi-Zhong, L., Gui-Tong, L., 2006. Modeling soil organic matter dynamics under intensive cropping systems on the Huang-Huai-Hai Plain of China. Pedosphere 16, 409-419.

Izaurralde, R.C., Williams, J.R., McGill, W.B., Rosenberg, N.J., Quirogas, Jakas, M.C., 2006. Simulating soil $C$ dynamics with EPIC: Model description and testing against long-term data. Ecol. Model. 192, 362-384.

Kobayashi, K., Salam, M.U., 2000. Comparing simulated and measured values using mean squared deviation and its components. Agron. J. 92, 345-352.

Lal, R., 2004. Soil carbon sequestration to mitigate climate change. Geoderma 123 , $1-22$.

Lal, R., Logan, T.J., Fausney, N.R., 1989. Long-term tillage and wheel traffic effects on a poorly drained Mollic Ochraqualf in Northwest Ohio. 1. Soil physical properties, root distribution and grain yield of corn and soybean. Soil Till. Res. 14, $341-$ 358.

Leite, L.F.C., Mendonca, E.S., Machado, P.L.O.A., 2004. Simulating trends in soil organic carbon of an Acrisol under no-tillage and disc-plough systems using the Century model. Geoderma 120, 283-295.

Lovato, T., Mielniczuck, J., Bayer, C., Vezzani, F., 2004. Adicão de carbono e nitrogênio e sua relacão com os estoques no solo e com o rendimento do milho em sistemas de manejo. Rev. Bras. Ci. Solo 28, 175-187.

Machado, P.L.O.A., Silva, C.A., 2001. Soil management under no-tillage systems in the tropics with special reference to Brazil. Nutr. Cycl. Agroecosyst. 61, 119130

Martin, J.P., Haider, K., 1986. Influence of mineral colloids on turnover rates of soil organic carbon. In: Huang, P.M., Schnitzer, M. (Eds.), Interactions of Soil Minerals With Natural Organics and Microbes. Soil Sci. Soc. Am. Special Publication 17, ASA, Madison, WI, pp. 283-304.

Mendonça, E.S., de Rowell, R.L., 1996. Mineral and organic fractions of two oxisols and their influence on effective cation-exchageable capacity. Soil Sci. Soc. Am. J. $60,1888-1892$.
Metay, A., Moreira, J.A.A., Bernoux, M., Boyer, T., Douzet, J.M., Feigl, B., Feller, C., Maraux, F., Oliver, R., Scopel, E., 2006. Storage and forms of organic carbon in a no-tillage under cover crop system on clayey Oxisol in dryland rice production (Cerrados Brazil). Soil Till. Res. 94, 122-132.

Neufeldt, H., Resck, D.R., Ayarza, M.A., 2002. Texture and land use effects on soil organic matter in Cerrado Oxisols, Central Brazil. Geoderma 107, 151164

Oades, J.M., 1988. The retention of organic matter in soils. Biogeochemistry 5, 35-70.

Oades, J.M., 1995. Kraznozems-organic matter. Aust. J. Soil Res. 33, 43-57.

Oades, J.M., Gillman, G.P., Uehara, G., 1989. Interactions of soil organic matter and variable-charge clays. In: Coleman, D.C., Oades, J.M., Uehara, G. (Eds.), Dynamics of Soil Organic Matter in Tropical Ecosystems. University of Hawaii, Niftal, pp. 69-95.

Oliveira, G.C., Dias-Junior, M.S., Resck, D.V.S., Curi, N., 2004. Caracterizacão química e físico-hídrica de um Latossolo Vermelho-Amarelo após vinte anos de manejo e cultivo do solo. Rev. Bras. Ci. Solo 28, 327-336.

Parton, W.J., Schimel, D.S., Cole, C.V., Ojima, D.S., 1987. Analysis of factors controlling soil organic matter levels in great plains grasslands. Soil Sci. Soc. Am. J. 51, 1173-1179.

Paustian, K., Six, J., Elliot, E.T., Hunt, H.W., 2000. Management options for reducing $\mathrm{CO}_{2}$ emissions from agricultural soils. Biogeochemistry 48, 147-163.

Renard, K.G., Foster, G.R., Weesies, G.A., McCool, D.K., Yoder, D.C., 1996. Predicting Soil Erosion by Water: A Guide to Conservation Planning With the Revised Universal Soil Loss Equation (RUSLE). U.S. Department of Agriculture, Agriculture Handbook No. 703, 404 pp.

Rickman, R.W., Douglas Jr., C.L., Albrecht, S.L., Bundy, L.G., Berc, J.L., 2001. CQESTR: a model to estimate carbon sequestration in agricultural soils. J. Soil Water Conserv. 56, 237-242.

Rickman, R., Douglas, C., Albrecht, S., Berc, J., 2002. Tillage, crop rotation, and organic amendment effect on changes in soil organic matter. Environ. Pollut. 116, 405411.

Roscoe, R., Buurman, P., 2003. Tillage effects on soil organic matter in density fractions of a Cerrado Oxisol. Soil Till. Res. 104, 185-202.

Salton, J.C., Mielniczuk, J., Bayer, C., Fabricio, A.C., Macedo, M.C.M., Broch, D.L., Boeni, M., Conceicao, P.C., 2005. Materia organica do solo na integracao lavourapecuaria em Mato Grosso do Sul. In: Embrapa Agropecuária Oeste, Dourados, Brazil, 57 pp.

Shang, C., Tiessen, H., 1997. Organic matter lability in a tropical oxisol: evidence from shifting cultivation, chemical oxidation, particle size, density, and magnetic fractionations. Soil Sci. 162, 795-807.

Shibu, M.E., Leffelaar, P.A., Van Keulen, H., Aggarwal, P.K., 2006. Quantitative description of soil organic matter dynamics-a review of approaches with reference to rice-based cropping systems. Geoderma 137, 1-18.

Silva, J.E., Lemainski, J., Resck, D.V.S., 1994. Perdas de matéria orgânica e suas relacoes com a capacidade de troca catiônica em solos da região de cerrados do oeste baiano. Rev. Bras. Ci. Solo. 18, 541-547.

Six, J., Elliot, E.T., Paustian, K., 1999. Aggregate and soil organic matter dynamics under conventional and no-tillage systems. Soil Sci. Soc. Am. J. 63, 1350-1358.

Six, J., Feller, C., Denef, K., Ogle, S.M., Sa, J.C.M., Albrecht, A., 2002. Soil organic matter, biota and aggregation in temperate and tropical soils-effects of notillage. Agron 22, 755-775.

Tiessen, H., Cuevas, E., 1994. The role of soil organic matter in sustaining soil fertility. Nature $371,783-785$

Tisdall, J.M., Oades, J.M., 1982. Organic matter and water stable aggregates in soil. J. Soil Sci. 33, 141-163.

William, J.R., Renard, K.G., 1985. Assessment of soil erosion and crop productivity with process models (EPIC). In: Follet, R.F., Stewart, B.A. (Eds.), Soil Erosion and Crop Productivity. American Society of Agronomy, Madison, WI, USA, pp. 68102

Yeomans, J.C., Bremner, J.M., 1988. A rapid and precise method for routine determination of organic carbon in soil. Commun. Soil Sci. Plant Anal. 19, 1467-1476.

Zinn, Y.L., Lal, R., Resck, D.V.S., 2005. Changes in soil organic carbon stocks under agriculture in Brazil. Soil Till. Res. 84, 28-40. 